ROCZNIKI PEDAGOGICZNE

Tom 11(47), numer 1 - 2019

DOI: http://dx.doi.org/10.18290/rped.2019.11.1-4

MAŁGORZATA ŁOBACZ

\title{
ISTOTA WYCHOWANIA INTEGRALNEGO W OSOBOWYM ROZWOJU CZŁOWIEKA
}

Każdy człowiek powinien rozwijać się integralnie i całościowo, a więc w wymiarach: fizycznym, psychicznym, moralnym, społecznym, kulturowym i religijnym. Pełna dbałość i troska o wszechstronny rozwój wychowanka stanowi właściwą odpowiedź na jego godność - jest działaniem nastawionym na rozwój jego osoby. Szczególną rolę w tak rozumianym wychowaniu człowieka ma do spełnienia wychowawca będący wzorem, który swoim zachowaniem, stosunkiem do innych i całym swoim życiem zaprasza wychowanków do uruchomienia wszelkich sfer życia ludzkiego, a tym samym do urzeczywistniania się jako osoba ludzka.

Celem niniejszego artykułu będzie próba ukazania znaczenia wychowania integralnego, ujmującego wszystkie sfery życia człowieka w osobowym rozwoju człowieka. W pierwszej kolejności przybliżony zostanie problem godności osobowej jako podstawowej wartości w relacji wychowawca-wychowanek. Następnie zaprezentowana zostanie rola wychowawcy w integralnym rozwoju człowieka. Całość artykułu zwieńczy refleksja nad znaczeniem wychowania integralnego w dochodzeniu do pełni człowieczeństwa.

\section{GODNOŚĆ OSOBOWA - PUNKTEM WYJŚCIA W WYCHOWANIU}

Wszelkie studia nad człowiekiem jako osobą ludzką zmierzają w kierunku ukazania fenomenu ludzkiego w jego wymiarze integralnym, nie znoszącym jakiegokolwiek uprzedmiotowienia człowieka i jego zinstrumentalizowania w różnorakich strukturach społeczno-prawnych, ekonomicznych czy wychowawczych.

Dr MaŁgorzata ŁobaCZ - Katedra Biografistyki Pedagogicznej, Instytut Pedagogiki, Katolicki Uniwersytet Lubelski Jana Pawła II; adres do korespondencji: ul. Droga Męczenników Majdanka 70, 20-325 Lublin; e-mail: gkolomanska@wp.pl 
Człowiek-osoba obdarzony jest godnością. Uświadomienie sobie tego faktu nie pozwala pozostać obojętnym, zobowiązuje do aktywności, stanowi źródło powinności afirmowania osoby przez osobę ze względu na przysługującą jej godność. Wobec drugiej osoby przejawia się to w szacunku do jej wartości, w gotowości do niesienia pomocy, a wobec siebie - w takim postępowaniu, które nie narusza podstawowych wskazań godności (Chudy, 2009).

Fakt bycia osobą ludzką wskazuje na naturalną wielkość człowieka, na jego nadrzędną pozycję wobec przyrody i tego, z czym spotyka się w świecie. Uznawać zatem godność osoby ludzkiej to tyle, co stawiać jego samego ponad wszystkim, co od niego pochodzi. Wszelkie ludzkie dzieła i wytwory są tylko środkami, którymi człowiek posługuje się w dążeniu do określonego celu (Wojtyła, 1994). Człowieka jako człowieka należy zatem zawsze traktować jako sam w sobie godny cel - dobro godziwe.

Podstawową wartością $\mathrm{w}$ procesie wychowania, punktem wyjścia $\mathrm{w}$ relacji wychowawca-wychowanek, nauczyciel-uczeń wyjątkowe miejsce zajmuje godność osoby ludzkiej. Stanowi ona fundamentalną wartość, przysługującą każdej osobie ludzkiej. Jest dana wszystkim ludziom, bez względu na stopień świadomości, zdrowia, zdolności, także niezależnie od zasług, posiadanego dorobku, czy wreszcie bez względu na to, z jakiej rodziny uczeń pochodzi. Wychowanie opiera się bowiem na rozpoznaniu godności. Człowiek dobrze wychowany, to „ktoś zdolny do odkrywania tego, co ważne” w drugim, jego najważniejszej wartości, którą jest godność osobowa (Chudy, 2009, s. 57).

Godność związana jest z samą naturą człowieka, jest jego wewnętrznym i wrodzonym znamieniem, niezależnym od kontekstu społecznego i historycznego. Świadomość własnej godności pociąga za sobą cały zespół wymagań wobec samego siebie. Na tym jednak nie poprzestaje, zobowiązuje także do szacunku wobec innych osób (Chrobak, 1999). Jest to niezwykle istotne w procesie wychowania. Wychowawca, respektujący swoją godność, nie będzie deprecjonował godności osobowej wychowanka, nie będzie go poniżał, ośmieszał ani upokarzał.

Najwyższym kryterium godności jest miłość, która nie dopuszcza do instrumentalnego traktowania człowieka. Świat osób w całym swym zakresie jest więc dla osoby - podmiotu działania moralnego - ,polem odpowiedzialnej miłości” (Szostek, 1996, s. 22). Ponadto godność osoby ludzkiej ,jest wartością w sobie i przez się, i wymaga, by traktowano ją jako taką, nigdy zaś jako przedmiot, który można użyć, narzędzie czy rzecz" (Jan Paweł II, 1999, nr 37). Granica godności jest naruszana wtedy, gdy jesteśmy uprzedmiotawiani, gdy nie jesteśmy traktowani jako rozumny i wolny podmiot własnych działań, a także w momencie 
traktowania drugiego - zwłaszcza słabszego człowieka - w sposób uwłaczający jego godności.

Prawidłowemu kształtowaniu się relacji wychowawca-wychowanek służyć ma wszystko - prawo, ustrój szkolny, organizacja, nadzór, programy, ale również nieoficjalne reguły tworzące się podczas sytuacji edukacyjnej. Relacja ta nie może być sprowadzona tylko do procesu dydaktycznego. Nauczyciel i uczeń są osobami, które powinny być w stałym dialogu, ogarniającym znacznie szerszy zakres zagadnień niż przekazywanie wiedzy.

Stosunki międzyludzkie w szkole, rozumianej jako wspólnota osób, są formowane przez zasadę normy personalistycznej, której pedagogicznym znaczeniem jest wartość stawania się osoby na drodze wzajemnych relacji. Personalizm wskazuje właściwy kierunek w budowaniu podmiotowych relacji międzyludzkich. Nurt ten przeciwstawia się bowiem przedmiotowemu traktowaniu człowieka. Podmiotowość oznacza przeciwieństwo uprzedmiotowienia. Przedmiot to jak sama nazwa wskazuje - coś, co znajduje się przed nami. Rzecz, którą można się posługiwać, pewien środek do osiągnięcia celu. Inaczej sprawa wygląda z podmiotem - to baza, fundament, cel sam w sobie, tu akcentuje się osobę ludzką jako sprawcę świadomych czynów, obdarzonego rozumem i wolną wolą.

Struktura osoby i jej godność stanowią od poczęcia do naturalnej śmierci człowieka jego niezbywalne i niezmienne elementy. Na tym opiera się sankcja etyczna, która zabrania wszelkich „zamachów” na te wartości (Chudy, 2004). Osoba ludzka jest wartością samą w sobie, dlatego wszelkie próby jej uprzedmiotowienia, traktowania jako środek do celu czy ataki na jej godność są zawsze złem. Niezależnie od czynów człowieka i od jego zasług czy nikczemności, zawsze należy traktować go z respektem dla jego godności.

W obecnych czasach często jeszcze dominuje ekonomizm wychowawczy $i$ instrumentalne traktowanie uczniów. Brak świadomości własnej godności i indywidualnej odpowiedzialności u ucznia powoduje w konsekwencji brak szacunku do szkoły i nauczycieli. Ponowoczesna koncepcja moralności, określana jako hiperinflacja moralna czy też reinterpretacja norm moralnych, dodatkowo stanowi poważne niebezpieczeństwo dla każdego człowieka. Świat pozbawiony wartości uniwersalnych, filarów, na których opierają się określone wzorce, wzory i modele zachowań, przeżywa wielki kryzys duchowy. Dochodzi do odwrócenia hierarchii wartości, następuje pustka duchowa, pojawia się konsumpcja i afery, rozwarstwienie socjalne na miliarderów i nędzarzy, sprowadzanie człowieka do poziomu zwierzęcia, nihilizm, rozpasanie seksualne, okrucieństwo i bezlitosna walka w każdej dziedzinie. Dlatego tak ważna jest refleksja wychowawców nad własną 
postawą wobec uczniów oraz wobec powinności nauczyciela, wychowawcy zobowiązani są także wyzwolić się z lęków i odważniej nawiązywać dialog ze swoimi podopiecznymi. Treści przekazywane uczniom winny sprzyjać kreowaniu modelu wychowania uczącego ich odpowiedzialności za własny rozwój i właściwą postawę w kontaktach z innymi (Niziołek, 2008).

$\mathrm{Z}$ drugiej strony $\mathrm{w}$ pracy wychowawczej można spotkać wiele przejawów braku posłuszeństwa wobec pedagogów. Obecna rzeczywistość kreowana jest bowiem przez trzy główne siły: konsumpcjonizm, mass-mediatyzację kultury i rozrywki oraz powszechną informatyzację społeczeństwa. Stąd też na terenie szkoły można zaobserwować przejawy źle rozumianej wolności, jak: lekceważący stosunek do nauczyciela, żucie gumy podczas lekcji, korzystanie w czasie zajęć z telefonów komórkowych czy smartwatchów.

Jednym z głównych źródeł współczesnego kryzysu wychowanków jest fakt, że w dzisiejszej dobie coraz bardziej dominuje humanistyczny model wychowania, oparty na zawężonej i naiwnej antropologii, a zatem na jednostronnej i nierealistycznej wizji człowieka. W tej sytuacji jednym z istotnych zadań wychowawców jest promocja wychowania integralnego, które ,obejmuje całego człowieka z jego niepowtarzalnym życiem fizycznym, psychicznym, społecznym, duchowym, religijnym i chroni go przed różnego rodzaju modnymi dziś a zarazem zgubnymi «redukcjonizmami», mającymi swoje korzenie w błędnym rozumieniu osoby ludzkiej”(Rynio, 2004, s. 17).

Integralne wychowanie - wskazujące drogę do osiągnięcia osobowej dojrzałości - winno rozpoczynać się już od najmłodszych lat. Jeżeli w okresie dzieciństwa człowiek zrozumie, kim jest osoba ludzka, jaką ma wartość, wówczas będzie afirmował siebie i drugiego. Bardzo ważna jest tutaj rola rodziny, szkoły i Kościoła. Pustka aksjologiczna okresu transformacji dodatkowo uzasadnia konieczność promowania takich wartości i postaw, jak: godność osobowa i szacunek dla godności drugiego człowieka, uczciwość oraz podmiotowość (Melosik, 2001).

\section{WZÓR OSOBOWY WYCHOWAWCY A CAŁOŚCIOWY ROZWÓJ CZŁOWIEKA}

Wychowanie stanowi pomoc w ,scalaniu się” człowieka, w jego dojrzewaniu i pokonywaniu ludzkiej niedoskonałości. Harmonizuje różnorakie poziomy człowieka, począwszy od najskromniejszych biegunów „natury”, skończywszy zaś na najbardziej kulturowo rozwiniętych i złożonych biegunach „ducha” (Cives, 1973). 
W wychowawczej pracy wychowawcy nad wychowankiem ujawnia się metafizyka pomocy. Wychowawca powinien wspomagać wychowanka przede wszystkim w tych wymiarach, które decydują o spełnianiu się człowieka jako osoby: rozumu, wolnej woli, ciała i godności osobowej. Spełnienie to jest pełne tylko wtedy, gdy pobudza wychowanka do samowychowania (Chudy, 2006). Bez wychowania oraz samowychowawczego trudu osoby byłaby ona ,albo bytem statycznym, niezmiennym ontologicznie, albo podlegałaby bez reszty zewnętrznym determinacjom" (Chudy, 2006, s. 67). Autentycznie wychowywać może jedynie prawdziwy mistrz - cierpliwy, wytrwały, pracowity, który dąży do pełnego rozwoju wychowanka. Do spotkania z takim nauczycielem dochodzi wyłącznie na gruncie miłości. Tylko wówczas ma on moc odmiany życia wychowanka.

Wychowawca, służąc swym wychowankom, sam wzrasta jako pedagog, uczony czy artysta. Dopiero, gdy uczy - i dzięki temu, że uczy - staje się coraz lepszym pedagogiem. Dojrzewa do tego, aby postawić dobro ucznia ponad swoim dobrem.

Stąd sercem działalności edukacyjnej szkoły jest to, co się dzieje w relacji nauczyciel-uczeń. Dlatego tak ważne jest, by kształtowaniu tej więzi służyły zarówno różne podmioty zaangażowane w funkcjonowanie szkoły, instytucje z nią współpracujące, jak też prawo, ustrój szkolny czy realizowany program. To wszystko bowiem sprzyja integralnemu rozwojowi młodego człowieka, albo nieodpowiednio funkcjonujące - może go zakłócać.

Mówiąc o charakterze relacji nauczyciel-uczeń warto przypomnieć, że wychowanie jest mało skuteczne, jeśli jest oparte na systemie nakazowo-zakazowym, sankcjach i strachu, który niszczy atmosferę wielu szkół. Zaufanie nauczyciela do ucznia wzbudza w uczniu zaufanie do nauczyciela. Ten szczególny mechanizm sprzężenia zwrotnego buduje zdrową, pozytywną motywację do nauki u ucznia i do pracy u nauczyciela. Wzajemna życzliwość i zaufanie, a także sprawiedliwość w ocenie osiągnięć ucznia stanowią właściwy punkt wyjścia do pracy edukacyjnej i zarazem warunek jej powodzenia.

Częściowe odsłonięcie siebie jako osoby wobec zgromadzonej na lekcji młodzieży, „uczłowieczenie” sztywnego często toku zajęć jest ważne dla nawiązania prawidłowych relacji osobowych nauczyciela z podopiecznymi. Tutaj nie pomoże ustrój szkoły, czy program dydaktyczny, lecz postępowanie oparte na nieformalnych regułach akceptowanych przez obie strony. To przez bliskość i dialog, wiodąc za sobą młodych ludzi, urzeczywistniając swym życiem wartości pożądane u swych podopiecznych, nauczyciele mogą najlepiej wypełniać swoje zadanie wychowawcze (Spychała, 2018). 
Bezinteresowna, niczym nie uwarunkowana miłość do dzieci stanowi bardzo ważny czynnik nauczycielskiego powołania. Wymaga ona pochylenia się nad wychowankami, rzetelnej znajomości dziecięcych potrzeb, wyjątkowo rozwiniętej empatii. Dzieci chcą widzieć w nauczycielu autorytet, ale nie oschły i odpychający, lecz pragną, aby zaimponował im jako mistrz.

Młody człowiek szuka autorytetów i chce powierzyć siebie drugiemu człowiekowi, którego uzna za człowieka wyjątkowo wartościowego. Bywa tak, że ta potrzeba zaufania prowadzi do pomyłek, fałszywych wyborów życiowych i rozczarowań. Dobry mistrz dba o własny rozwój, jest człowiekiem dojrzałym i ma dystans do siebie. Mistrz wpływa na życie ucznia na różnych poziomach, daje pouczcie siły, wiary we własne możliwości, motywuje.

W etos nauczyciela wpisane są takie cechy, jak: pracowitość, umiejętne stawianie wymagań oraz sprawiedliwość w ocenach, optymizm pedagogiczny, takt i pełna akceptacja każdego ucznia, stanie na straży ładu moralnego, poszanowanie wartości uniwersalnych oraz praw człowieka. Rolą nauczyciela jest również przeciwdziałanie licznym zagrożeniom: $\mathrm{m}$. in. negatywnemu oddziaływaniu mediów, nałogom, relatywizmowi moralnemu, permisywizmowi i wszelkim patologiom, występującym w wielu sferach. Zadanie to może spełnić tylko wówczas, gdy będzie wielkim nauczycielem i wielkim człowiekiem. Wtedy bowiem będzie mógł przekazać pełną wiedzę, nauczyć myślenia i wskazać kierunek mądrego życia (Rusiecki, 2008).

Najlepszą metodą wychowawczą jest niewątpliwie świadectwo, „polegające na takim odnoszeniu się do innych w codziennym życiu, że - poprzez respekt dla nich, delikatność i wrażliwość w ich traktowaniu - ukazywana zostaje (albo przynajmniej zasugerowana) wartość, która jest motywem takiego odnoszenia. Godność osobową «ja» najlepiej ukazywać przez odniesienie do «ty» lub do osoby trzeciej” (Chudy, 2006, s. 68). Tylko taka metoda, w której nauczyciel swoim postępowaniem wobec innych stanowi wzór do naśladowania, pozwala na autentyczne doświadczenie godności. Nie można nauczyć nikogo godności.

Wartości przeżywane przez wzór osobowy - zwłaszcza wartość godności osobowej - mogący być dla młodego człowieka bohaterem, przenikając jego egzystencję i kształtując osobowość, mogą w końcu być przekazywane innym, wpływać na ich postawy, słowa i postępowanie. Wzór osobowy, z którym wychowanek na co dzień przebywa, często obserwowany, wprowadza w świat wartości, dzięki naturalnej tendencji młodych ludzi do poszukiwania ideału godnego naśladowania. Bohaterowi, który jest wzorem osobowym, ma towarzyszyć właściwa koncepcja wolności człowieka, opartej na wartościach. Istotne 
jest również wskazywanie właściwych motywów, by pomóc w urzeczywistnianiu tego, co słuszne (Noga, 2004).

Wychowawca, będący wzorem osobowym i autorytetem moralnym, wychowuje do wartości, szanując autonomię wychowanka. Takie wychowanie pozbawione jest przymusu i jest współdziałaniem wychowawcy i wychowanka, odwoływaniem się do doświadczeń wychowawcy oraz sposobu rozumienia i przyjmowania wartości. Przyjęcie określonej koncepcji wartości i związanej z nią koncepcji człowieka prowadzi do wyboru i akceptacji przez wychowanka aprobowanej społecznie hierarchii wartości.

W koncepcji wychowania personalistycznego wzór osobowy, będący jednocześnie autorytetem moralnym, jest nosicielem wartości. Jest świadomy swej odpowiedzialności, zaś szanując godność osoby ludzkiej jest otwarty na innych oraz na otaczającą go rzeczywistość. To sprawia, że będąc wolnym prowadzi innych do wolności (Noga, 2004).

Nauczyciel - chcący zbudować autorytet w oczach swoich uczniów - nie może domagać się, aby uczniowie go szanowali, podziwiali, słuchali, naśladowali, czerpali wiele dla siebie z jego postawy, tylko dlatego, że pełni on funkcję wobec nich nadrzędną, jest ich przełożonym - nauczycielem. Musi on zabiegać całym sobą w kontaktach $\mathrm{z}$ wychowankami, aby dobrowolnie uznali, że warto mieć w jego postawie i przekonaniach punkt odniesienia. Aby w sposób owocny towarzyszyć wychowankom w szkole w dorastaniu do bogatszego człowieczeństwa, wychowawca powinien mieć solidne kompetencje z zakresu antropologii i nauk o wychowaniu.

\section{WYCHOWANIE INTEGRALNE A DOCHODZENIE DO PEŁNI CZŁOWIECZEŃSTWA}

Człowiek nie jest bytem doskonałym, „domkniętym”, „zakończonym” w kształcie swojego człowieczeństwa. Owa przygodność, kruchość istnienia, bliska każdej osobie ludzkiej wskazuje, że każdy człowiek potrzebuje pomocy. „Pierwszym i podstawowym faktem kulturalnym jest sam człowiek duchowo dojrzały - czyli człowiek w pełni wychowany, autentycznie bogaty, zdolny wychowywać samego siebie i drugich" (Jan Paweł II, 1980, s. 4). Dlatego też fundamentalnym zadaniem kultury jest wychowanie, czyli pomoc w pokonaniu tej egzystencjalnej słabości, a tym samym - w osiąganiu pełni człowieczeństwa. „W wychowaniu bowiem chodzi właśnie o to, ażeby człowiek stawał się coraz 
bardziej człowiekiem - o to, ażeby bardziej «był», a nie tylko więcej «miał» aby więc poprzez wszystko, co «ma», co «posiada», umiał bardziej i pełniej być człowiekiem", stawał się bogatszy w swym człowieczeństwie (Jan Paweł II, 1980, s. 4). Wychowanie - zgodnie z określeniem wskazanym przez Jana Pawła II - jest to proces doskonalenia się człowieka, zmierzający do aktualizowania pełni jego człowieczeństwa poprzez odkrywanie prawdy o sobie i świecie (Jan Paweł II, 1980). Z kolei Klaus Schaller podkreśla, że wychowanie, to „sposoby i procesy, które pozwalają wychowankowi odnaleźć się w swoim człowieczeństwie" (Nowak, 2000, s. 289).

Wychowanie w znacznym stopniu polega na docenieniu jednostki, która jest nieskończona, a tym samym na uznaniu formacji za proces nigdy niedokończony, za dzieło narażone na niepowodzenie, nieprzewidywalne, a jednocześnie konkretne i żywe (Pesci, 2006). Pierwszorzędnym walorem wychowawczej pracy nad wychowankiem-osobą jest jego integralny rozwój. Człowiek - chcąc niejako wyjść ponad współczesne zagrożenia, chcąc je pokonać - winien rozwijać się integralnie, to znaczy w wymiarach: fizycznym, psychicznym i moralnym, społecznym, kulturowym i religijnym.

Brak wychowania, rozumianego wieloaspektowo, integralnie, sprowadza życie człowieka do biernej egzystencji z jednej strony, z drugiej zaś powoduje bezwiedne uleganie różnorodnym zewnętrznym naciskom, co dziś często możemy dostrzec - uleganie modzie, presji otoczenia często za cenę wewnętrznego niepokoju, niedosytu, a także chorób (Chudy, 2006, s. 67). Dlatego też każdy wybór w kierunku dobra oraz pokonywanie własnych słabości stanowią o rozwoju człowieka jako osoby. Pokonywanie swej egzystencjalnej kruchości, to budowanie przez osobę ludzką cnoty, której fundament stanowi godność osobowa. To wreszcie wychowanie charakteru i praca nad cnotami moralnymi.

Istnieją chrześcijańskie drogi ukazywania przez wychowawcę dojrzałości osobowej. Na ten fakt wskazał Jan Paweł II, mówiąc: nauczyciel ,winien starać się o wzrost w uczniach [...] wiary w Boga Stwórcę, podziwu dla rzeczy przez Niego stworzonych, miłości dla braci, cnót prostoty, pokory, umiarkowania, posłuszeństwa [...], które uzupełniają się i harmonizują [...] z samym ideałem autentycznie ludzkiego wychowania" (Jan Paweł II, 1992, s. 647).

Kultura, która wychowuje, warunkuje rozwój ludzi, jest zespołem szans i niczym niezastąpionych możliwości; źle wykorzystana może prowadzić do zagrożeń, zakłócać i deformować proces wychowania oraz dokonywać jego destrukcji (Ożóg, 2000). Współcześnie coraz częściej preferuje się łatwość i wygodę, sukces, karierę, efektowny zysk, atrakcyjność i młodość. Charakterystyczne 
dla tej kultury hasła, to: „,skorzystać”, „,wykorzystać okazje”, ,załapać się”, „promować" i inne. Dlatego coraz większy niepokój budzi swoiste odwrócenie ról, jakie przeżywa kultura współczesna, nie tyle żywiąc przy pomocy piękna zbiorową świadomość i wyobraźnię, co sama karmiąc się odpadkami życia społecznego i zachęcając do przyjmowania postawy nastawionej na materializm i konsumpcjonizm. Odmowa uszanowania tego, co rzeczywiście święte, sprawia zaś, że pojawiają się świętości fałszywe. Coraz częściej przyczyną pustki moralnej jest fakt, że człowiek zatraca niejednokrotnie zdolność panowania nad sobą oraz nie potrafi przeciwstawić się destruktywnym wpływom stworzonej przez siebie cywilizacji naukowo-technicznej, noszącej znamiona cywilizacji śmierci.

Takie zachowania są również następstwem negatywnego rozumienia wolności, pojmowanej jako brak nakazów i zakazów, wyjętej poza kategorie dobra i zła. Jan Paweł II, przestrzegając przed tym niebezpieczeństwem, nakazuje, by dobrze używać wolności. „Trzeba umieć używać swojej wolności, wybierając to, co jest prawdziwym dobrem. Nie dajcie się zniewolić! Nie dajcie się skusić pseudowartościami, półprawdami, urokiem miraży, od których później będziecie się odwracać z rozczarowaniem, poranieni, a może nawet ze złamanym życiem" (Jan Paweł II, 2005). Przeżywany przez wielu relatywizm, czy wręcz nihilizm aksjologiczny, pokazał, że wolność absolutną, wolność od wszelkich ograniczeń, w konsekwencji człowiek odczuwa jako bezkresną rozpacz.

Ofiarami tych wszystkich wypaczeń moralnych: indywidualizmu, pluralizmu zasad, subiektywizmu wartości i norm, są w szczególności młodzi ludzie. Oni to, żyjąc w świecie odartym z norm regulujących stosunek człowieka do człowieka i do samego siebie, są najbardziej głodni miłości, czułości i poczucia bezpieczeństwa. Poszukując tych wartości, uciekają nierzadko w świat narkotyków, konsumpcjonizmu, dopuszczają się agresji wobec innych czy samego siebie.

$\mathrm{Z}$ pomocą tym młodym ludziom zobowiązani są wyjść naprzeciw przede wszystkim wychowawcy. Oni, obok rodziców, powinni wskazywać wychowankom właściwy wybór wartości. Jednak sami nauczyciele, żyjący w społeczeństwie pluralistycznym, mają na tym polu wiele trudności. W otaczającym ich świecie przyznaje się bowiem pierwszeństwo często nie tyle wartościom podstawowym, do których zalicza się wartości moralne, obyczajowe, religijne i poznawcze, ile raczej bogactwom materialnym, technicznym, czy też wartościom hedonistycznym.

Dzieje się tak dlatego, ponieważ ,wielu nie odkryło jeszcze, że stajemy się osobami i sprawiamy, że stają się nimi inni dzięki poszanowaniu, otwarciu, 
miłości, pomocy, właściwie i dogłębnie rozumianej łączności z innymi” (Valwerde, 1998, s. 337-338). Postawa otwarcia się na innych wymaga trudu i ciągłej uwagi skierowanej w stronę wartości moralnej swoich czynów. W czynie bowiem realizuje się rzeczywistość aksjologiczna, a przede wszystkim „rzeczywistość ontologiczna, rzeczywistość spełnienia siebie przez czyn, co właściwe jest tylko osobie" (Wojtyła, 1994, s. 196).

Integralne rozumienie procesu wychowania akcentuje, by uwzględniać w wychowaniu wszystkie podstawowe sfery człowieczeństwa, a zatem sferę fizyczną, psychiczną, moralną, kulturową, religijną oraz społeczną. Z kolei rozumienie realistyczne wychowanka oznacza, że wychowawca zdaje sobie sprawę zarówno z jego wielkości i niezwykłości, jak i ograniczeń oraz słabości. Każdy z wychowanków - z pomocą rodziców i innych wychowawców - stopniowo odkrywa własne bogactwo. Najpierw odkrywa swoje ciało, a następnie psychikę, a zwłaszcza swoje przeżycia emocjonalne. Później dopiero odkrywa sferę moralną, duchową, społeczną i religijną. Tym, co łączy wszystkie te wymiary człowieczeństwa i co nadaje im sens, jest osoba, która przekracza ograniczenia i możliwości własnego człowieczeństwa.

\section{BIBLIOGRAFIA}

CHRовак, S. (1999). Koncepcja wychowania personalistycznego w nauczaniu Karola Wojtyty - Jana Pawta II. Warszawa: Wydawnictwo Salezjańskie.

Chudy, W. (2004). Być a stawać się osobą. Zeszyty Karmelitańskie, 4 (29), 30-36.

Chudy, W. (2006). Istota pedagogiki personalistycznej. Ethos, 75, 52-74.

Chudy, W. (2009). Pedagogia godności. Elementy etyki pedagogicznej (red. A. Szudra). Lublin: TN KUL.

Cives, G. (1973). La mediazione pedagogica. Firenze: La Nuova Italia.

Jan PAweŁ II. (1999). Posynodalna Adhortacja apostolska Christifideles laici. Wrocław: Wydawnictwo Wrocławskiej Księgarni Archidiecezjalnej.

JAN PAweŁ II. (2005). Przemówienie Jana Pawła II do młodzieży w Poznaniu, Poznań, Plac Adama Mickiewicza, 3. 06. 1997. W: Jan Pawet II, Pielgrzymki do Ojczyzny. Przemówienia i homilie (s. 917-924). Kraków: Znak.

JAN PAWEe II. (1980). W imię przyszłości kultury. (Przemówienie do przedstawicieli UNESCO, Paryż 2.06.1980). L' Osservatore Romano, 6, 4-6. 
JAN PAWEe II. (1992). Świadczyć o Chrystusie przykładem życia. Do nauczycieli katolickich (Przemówienie podczas audiencji dla nauczycieli XII Krajowego Zjazdu Włoskiego Stowarzyszenia Nauczycieli Katolickich, Sala klementyńska, Watykan, 7 XII 1979). W: E. Weron i A. JAROCH (red.), Nauczanie papieskie. T. II. Cz. 2 (s. 645-648). Poznań: Pallottinum.

MelosiK, Z. (2001). Młodzież i styl życia: paradoksy pop-tożsamości. W: Z. MelosıK (red.), Młodzież, styl życia i zdrowie. Konteksty i kontrowersje (s. 11-57). Poznań: Wolumin.

NizıOŁEK, B. (2008). Kilka uwag o wychowaniu. Wychowawca, 2, 5-6.

Noga, H. (2004). Wzór osobowy jako nośnik wartości. Wychowawca, 6, 11-12.

NowaK, M. (2000). Podstawy pedagogiki otwartej. Lublin: RW KUL.

OżóG, T. (2000). Kulturowe zagrożenia wychowania. W: M. NowAK i T. OżóG (red.), Wychowanie chrześcijańskie a kultura (s. 167-188). Lublin: RW KUL.

Pesci, F. (2006). Filozoficzna perspektywa wychowania (tł. P. Mikulska). Ethos, 75, 37-51.

RUSIECKI, M. (2008). Etos nauczycielski. Kieleckie Studia Teologiczne 7, 277-299.

RYNIO, A. (2004). Integralne wychowanie w myśli Jana Pawła II. Lublin: KUL.

SpychaŁA, A. Relacje nauczyciel-uczeń w procesie nauczania, w: http://www.profesor.pl/mat/n10/ pokaz_material_tmp.php?plik=n10/n10_a_spychala_040509_2.php\&id_m=10872 (02.08.2018).

SzosteK, A. (1996). Pogadanki z etyki. Lublin: RW KUL.

VAlwerde, C. (1998). Antropologia filozoficzna (tt. G. Ostrowski). Poznań: Pallottinum.

WojTYŁA, K. (1994). Osoba i czyn oraz inne studia antropologiczne. Lublin: Towarzystwo Naukowe KUL.

\section{ISTOTA WYCHOWANIA INTEGRALNEGO W OSOBOWYM ROZWOJU CZŁOWIEKA}

$$
\text { Streszczenie }
$$

Wychowanie integralne człowieka - czyli wielowymiarowe i pełne rozumienie procesu wychowania wskazuje na uwzględnienie wszystkich podstawowych sfer człowieczeństwa: cielesnej, płciowej, seksualnej, intelektualnej, emocjonalnej, moralnej, duchowej, religijnej, społecznej. Tak rozumiany proces wychowania człowieka jest optymalny i prowadzi do rozwoju osobowego człowieka. Aby mógł on przebiegać prawidłowo, konieczna jest afirmacja wartości godności osobowej, która stanowi punkt wyjścia w relacji wychowawca-wychowanek. Bardzo ważne jest także, by sam wychowawca był wzorem - prawdziwym mistrzem, który swoim przykładem pokieruje wychowanka w stronę pełnego rozwoju osobowego.

Integralne wychowanie - wskazujące drogę do realizacji człowieczeństwa człowieka - powinno rozpoczynać się już od najmłodszych lat. Jeżeli człowiek we wczesnych latach swojego życia zrozumie wartość osoby ludzkiej oraz istotę integralnego jej rozwoju, wówczas pozna sens życia ludzkiego i zadanie wynikające z faktu „bycia” człowiekiem.

Słowa kluczowe: wychowanie integralne; rozwój osobowy; wychowawca; godność. 


\title{
THE ESSENCE OF AN INTEGRAL EDUCATION IN THE PERSONAL DEVELOPMENT OF A MAN
}

\begin{abstract}
S u m m a ry
Integral education of a man - that is multidimensional and complete understanding of the educational process indicates taking into account all basic spheres of humanity: physical, sexual, intellectual, emotional, moral, spiritual, religious, and social. Such understanding of the educational process is optimal and leads to personal development. To carry it out correctly, affirmation of the values of dignity is necessary, which is the starting point in the relationship educator-graduate. It is also very important that the educator is a role-model - a true master, who will lead the student towards full personal development.

Integral education - indicating the way to the implementation of the humanity of a man - should start at an early age. If a person, in their early years of life, understands the value of a person and the essence of integral development, then they will know the meaning of human life and the task arising out of "being" a human.
\end{abstract}

Key words: integral education; personal development; educator; dignity. 